\title{
Prevalence of virulence and antimicrobial resistance genes in Salmonella spp. isolated from commercial chickens and human clinical isolates from South Africa and Brazil
}

\begin{tabular}{|c|c|}
\hline \multicolumn{2}{|c|}{$\begin{array}{l}\text { Authors: } \\
\text { Oliver T. Zishiri }{ }^{1} \\
\text { Nelisiwe Mkhize }^{1} \\
\text { Samson Mukaratirwa }^{1}\end{array}$} \\
\hline \multicolumn{2}{|c|}{$\begin{array}{l}\text { Affiliations: } \\
{ }^{1} \text { Department of Genetics, } \\
\text { University of KwaZulu-Natal, } \\
\text { South Africa }\end{array}$} \\
\hline \multicolumn{2}{|c|}{$\begin{array}{l}\text { Corresponding auth } \\
\text { Oliver Zishiri, } \\
\text { zishiri@ukzn.ac.za }\end{array}$} \\
\hline \multicolumn{2}{|c|}{$\begin{array}{l}\text { Dates: } \\
\text { Received: } 30 \text { Sept. } 2015 \\
\text { Accepted: } 11 \text { Dec. } 2015 \\
\text { Published: } 26 \text { May } 2016\end{array}$} \\
\hline \multicolumn{2}{|c|}{$\begin{array}{l}\text { How to cite this article: } \\
\text { Zishiri, O.T., Mkhize, N. \& } \\
\text { Mukaratirwa, S., 2016, } \\
\text { 'Prevalence of virulence and } \\
\text { antimicrobial resistance } \\
\text { genes in Salmonella spp. } \\
\text { isolated from commercial } \\
\text { chickens and human clinical } \\
\text { isolates from South Africa } \\
\text { and Brazil', Onderstepoort } \\
\text { Journal of Veterinary } \\
\text { Research } 83(1), \text { a1067. } \\
\text { http://dx.doi.org/10.4102/ } \\
\text { ojvr.v83i1.1067 }\end{array}$} \\
\hline \multicolumn{2}{|c|}{$\begin{array}{l}\text { Copyright: } \\
\text { (C) 2016. The Authors } \\
\text { Licensee: AOSIS. This } \\
\text { is licensed under the } \\
\text { Creative Commons } \\
\text { Attribution License. }\end{array}$} \\
\hline \multicolumn{2}{|l|}{ Read online: } \\
\hline 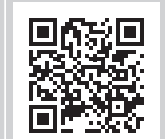 & $\begin{array}{l}\text { Scan this QR } \\
\text { code with your } \\
\text { smart phone or } \\
\text { mobile device } \\
\text { to read online. }\end{array}$ \\
\hline
\end{tabular}

Salmonellosis is a significant public health concern around the world. The injudicious use of antimicrobial agents in poultry production for treatment, growth promotion and prophylaxis has resulted in the emergence of drug-resistant strains of Salmonella. The current study was conducted to investigate the prevalence of virulence and antimicrobial resistance genes from Salmonella isolated from South African and Brazilian broiler chickens as well as human clinical isolates. Out of a total of 200 chicken samples that were collected from South Africa 102 (51\%) tested positive for Salmonella using the InvA gene. Of the overall 146 Salmonella-positive samples that were screened for the iroB gene, most of them were confirmed to be Salmonella enterica with high prevalence rates. All the Salmonella isolates obtained were subjected to antimicrobial susceptibility testing with ten antibiotics. Salmonella isolates from South African chickens exhibited resistance to almost all antimicrobial agents used. All the samples were further subjected to the Polymerase Chain Reaction in order to screen some common antimicrobial and virulence genes of interest, namely spiC, pipD, misL, orfL, pse-1, tet $A$, tet $B$, ant (3")-la, sul 1 and sul. All the Salmonella-positive isolates exhibited resistance to at least one antimicrobial agent; however, antimicrobial resistance patterns demonstrated that multiple drug resistance was prevalent. The findings provide evidence that broiler chickens are colonised by pathogenic Salmonella harbouring antimicrobial resistance genes. Therefore, it is evident that there is a need for prudent use of antimicrobial agents in poultry production systems in order to mitigate the proliferation of multiple drug resistance across species.

\section{Introduction}

The increasing human population around the world places a huge demand on food in order to ensure the survival of mankind. This exerts pressure on a number of food industries such as poultry production systems, where growth promotion agents are used in an effort to satisfy the increasing food demand. The presence of Salmonella in chicken meat and its related products has often caused them to be unsafe for human consumption (Centers for Disease Control [CDC] 2013). Salmonella is classified as one of the most common zoonotic foodborne pathogens that cause outbreaks and sporadic cases of gastroenteritis in humans throughout the world (Humphrey 2000). In the United States of America a total of 19531 infections, 4563 hospitalisations and 68 deaths associated with foodborne diseases were reported in 2012 (CDC 2013). Epidemiological studies have reported numerous times that foods of animal origin, particularly poultry, are major vehicles associated with illnesses caused by Salmonella (Dallal et al. 2010). Salmonella can grow as surface-associated aggregates on food surfaces and equipment (Chia et al. 2009), commonly described as biofilms. The cells that develop as biofilms are potential sources of contamination on food products, which can result in infection in human hosts (Chia et al. 2009).

The reservoir of Salmonella is the gastro-intestinal tract (GIT) of a wide range of domestic and wild animals, and a variety of foodstuffs of both animal and plant origins are potential sources of infection (Thong et al. 2002; Thorns 2000). According to the Centers for Disease Control and Prevention (CDC) the genus Salmonella is divided into two species, Salmonella enterica and Salmonella bongori (CDC 2013). The species S. enterica is further subdivided into six subspecies that are designated by taxonomic names such as S. enterica subsp. enterica, S. enterica subsp. salamae, S. enterica subsp. arizonae, S. enterica subsp. diarizonae, S. enterica subsp. houtenae and S. enterica subsp. indica (CDC 2013). Salmonella is associated with approximately 2500 serovars. These serovars are separated based on differences in their lipopolysaccharide layer with regard to their 
somatic $(\mathrm{O})$ and flagellar $(\mathrm{H})$ antigens (Amagliani, Brandi \& Schiavano 2012). With regard to the $\mathrm{O}$ antigen, Salmonella is divided into 50 serogroups and then further divided into more than 2500 serovars based on the $\mathrm{H}$ antigens present (Amagliani et al. 2012). The majority of the serovars of Salmonella belong to S. enterica and the most common serovar associated with zoonotic infection is Salmonella enteriditis, followed by Salmonella typhimurium (Amagliani et al. 2012). Serovars that are generally found in food products of animal origin include $S$. enteriditis, S. typhimurium, Salmonella gallinarum, Salmonella weltevreden and Salmonella infantis (Foley et al. 2011). Salmonellosis in both humans and animals results from various vehicles of Salmonella serovars such as S. enteritidis, S. infantis, Salmonella kentucky, and Salmonella Heidelberg. These vehicles that cause infection appear to be more prevalent in poultry than in any other food animal (Foley et al. 2011).

The ability of bacteria to infect the host relies on the genetic determinants called virulence genes, located in the Salmonella pathogenicity islands (SPI). According to Groisman and Ochman (1997), SPIs are portions of DNA that have been acquired from other microorganisms by horizontal gene transfer and they are absent in non-pathogenic strains. At least 60 virulence genes associated with SPIs (Groisman \& Ochman 1997) have been mapped so far and they all serve different functions. Some facilitate colonisation for the pathogen to survive host defence mechanisms and some are responsible for multiplication inside the host. However, during contamination the host infection outcomes depend on various factors such as age, environment and genetics to influence the host status (Van Asten \& Dijk 2005). A wellknown virulence gene in Salmonella is the Salmonella invasion gene A (invA), which is responsible for host invasion (Galan, Ginocchio \& Costeas 1992). This gene is vital because it is conserved in all Salmonella and is found in SPI-1. Hence it is used by researchers as a marker to detect Salmonella isolated from different sources.

Various studies from both developed and developing countries have focused on investigating the prevalence of genes encoding for virulence in Salmonella. These countries include the United States of America (Zou et al. 2011), Senegal and Gambia (Dione et al. 2011), Brazil (Borges et al. 2013; Dias De Olivieira et al. 2003) and Nigeria (Smith et al. 2015). In South Africa information on the prevalence of virulence genes in Salmonella of animal and human origin is limited. Therefore, these among other facts motivated us to embark on the current study in which we evaluated the prevalence of virulence genes in Salmonella such as InvA, spiC, pipD, misL and orfL. The Sip proteins, which include $\operatorname{Sip} A, \operatorname{Sip} B, \operatorname{Sip} C$ and $\operatorname{SipD}$, were some of the first virulence genes to be characterised in Salmonella based on their involvement in the invasion of cultured epithelial cells (Kaniga, Trollinger \& Galan 1995). SipC is directly involved in the translocation process and is delivered to the cytosol of the host cell, where it may also have an effector function (Hersh et al. 1999). The SpiC gene was investigated in this study because it is involved in the interaction with the intercellular membrane and trafficking, thereby hindering correct cellular function (Uchiya \& Nikai 2008). The misL is an SPI-3 encoded protein that is involved in other aspects of pathogenesis such as chronic infection and host specificity (Blanc-Potard et al. 1999). The orfL virulence gene is found in SPI-4 and is involved in adhesion, autotransportation and colonisation (Hughes et al. 2008). Another important virulence gene is the pipD, which is found in SPI-5 and is a type III secreted effector associated with the SPI-1 system (Hughes et al. 2008).

The use of antimicrobial agents in poultry production for treatment purposes, growth promotion and prophylaxis raises a major concern with regard to antimicrobial resistance and multidrug resistance, which are frequently observed among many Salmonella serovars (Duong et al. 2006). Increasing evidence demonstrates that antimicrobial usage in animals promotes the emergence of a wide range of resistant zoonotic pathogens such as Salmonella, which compromises the effectiveness of antibiotic treatments used in humans when an infection occurs (Gyles 2008). The variety of antibiotics that are administered in veterinary practice therapeutically has caused selective pressure, resulting in an increase in genetic sequences that confer resistance on microorganisms. Antimicrobial-resistant Salmonella has been recognised as a public health concern for decades in developed and developing countries and the evolving resistance in this pathogen limits the therapeutic options available to physicians for the treatment of human salmonellosis (Foley et al. 2011). Extensive use of antibiotics in chicken production systems for non-therapeutic purposes such as growth promotion results in the resistance of bacteria to these antimicrobial agents. Bacteria use both natural and acquired resistance mechanisms to protect themselves against agents that could harm them. Acquired resistance arises from mutations, gene transfer by conjugation or transformation, transposons, integrons and bacteriophages (Cogliani, Goossens \& Greko 2011).

It is therefore necessary to determine bacterial resistance to antibiotics of all classes, the phenotypes they exhibit and the mutations responsible for resistance using molecular genetic analysis methods. The impact of antimicrobial resistance on human health is of great concern for the treatment of various infections that arise from food of animal origin (Glenn et al. 2011), where combinations of broad-spectrum antibiotics need to be administered in order to control infection. Therefore, understanding the mechanisms of antibiotic resistance, the location of genes on a chromosome or plasmid and their expression will assist in developing screening and control strategies that are urgently needed in order to reduce the spread and evolution of resistant bacteria. Against this background, this study aimed to investigate the prevalence of virulence and antimicrobial resistance genes in chicken samples from South Africa as well as imports from Brazil and human clinical isolates. Genetic characterisation of the antimicrobial resistance and virulence genes present in Salmonella is essential in understanding the pathogenicity and prevalence of resistance that exists in this zoonotic foodborne pathogen. 


\section{Materials and methods Sample collection}

Broiler chicken caecum samples were collected on the day of slaughter from poultry slaughterhouses within the Durban metropolitan area in KwaZulu-Natal province of South Africa between March and October 2014. Samples were collected in batches of 25 per month. In total 200 samples were randomly collected over the eight-month period. All the samples were aseptically collected in plastic screw-top tubes containing $45 \mathrm{~mL}$ of $0.1 \% \mathrm{w} / \mathrm{v}$ peptonewater and stored on ice until transported back to the University of Kwa-Zulu Natal (Westville Campus), where enrichment of the samples was done immediately on arrival. South Africa imports more than $50 \%$ of chicken products from Brazil because domestic production cannot meet the current demand. Whenever chicken products are imported in batches from other countries such as Brazil, quality assurance, routine disease surveillance, screening and testing are conducted before the products are conveyed to the food chain. It was therefore crucial to include some samples that originated from Brazil in our study. Accordingly, Salmonella isolates from Brazilian broiler chickens (24) and human clinical samples (20) from patients emanating from the coastal region of KwaZulu-Natal province in South Africa were provided by the National Health Laboratory Service of South Africa.

\section{Enrichment}

Enrichment was carried on South African (SABC) chicken samples only. Ten millilitres of rinse peptone-water from the samples were incubated at $37{ }^{\circ} \mathrm{C}$ for $24 \mathrm{~h}$. After incubation $0.1 \mathrm{~mL}$ aliquots from the peptone-water samples were inoculated into tubes containing $10 \mathrm{~mL}$ of Rappaport Vassiliadis (RV) broth medium and incubated at $42{ }^{\circ} \mathrm{C}$ for $48 \mathrm{~h}$ (Ahmed \& Shimamoto 2012).

\section{Microbiological analysis}

After enrichment, a loopful of the broth culture was streaked onto xylose-lysine-deoxycholate (XLD) agar plates and incubated at $37{ }^{\circ} \mathrm{C}$ for $24 \mathrm{~h}$. Black colonies with typical phenotypic characteristics were regarded as suspect Salmonella. Suspected Salmonella colonies were picked and inoculated on TSB broth and incubated while shaking at $37{ }^{\circ} \mathrm{C}$ for $24 \mathrm{~h}$. The resulting culture was used for DNA extraction and some was used for susceptibility tests. The remaining culture was used for $60 \%$ glycerol stocks that were then stored at $-80{ }^{\circ} \mathrm{C}$ for future purposes.

\section{DNA extraction}

Genomic DNA of all the Salmonella isolates was extracted from the culture using the ZymoResearch Fungal and Bacterial Genomic DNA MiniPrep ${ }^{\mathrm{TM}}$ kit following the manufacturer's instructions. A positive Salmonella control was prepared by isolating genomic DNA from a reference strain of known Salmonella broth culture. After DNA extraction, a NanoDrop Spectrophotometer was used to check the concentration and quality of the isolated DNA and extracted DNA was then stored at $-20{ }^{\circ} \mathrm{C}$ until use in Polymerase Chain Reaction (PCR).

\section{Confirmation of Salmonella using Polymerase Chain Reaction}

PCR was performed on the DNA extracted from all the detected and obtained samples. The invA gene was used to confirm the presence of Salmonella. A $25 \mu \mathrm{L}$ PCR reaction was used for amplification of the invA gene. The primers used for detection of the invA gene are presented in Table 1. The PCR reaction was carried out in a total volume of $25 \mu \mathrm{L}$ containing $12.5 \mu \mathrm{L}$ DreamTaq Green PCR Master Mix, $1 \mu \mathrm{L}$ invA primer (forward), $1 \mu \mathrm{L}$ inv A primer (reverse), $4 \mu \mathrm{L}$ of

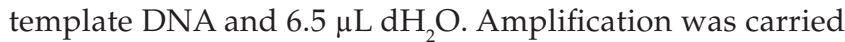
out in a thermo-cycler using 34 cycles consisting of denaturation for $30 \mathrm{~s}$ at $95{ }^{\circ} \mathrm{C}$, annealing for $30 \mathrm{~s}$ at $58{ }^{\circ} \mathrm{C}$, extension for $1 \mathrm{~min}$ at $72{ }^{\circ} \mathrm{C}$ and final extension for $5 \mathrm{~min}$ at $72{ }^{\circ} \mathrm{C}$. PCR products were run on a $1.5 \%$ agarose gel using electrophoresis at 70 volts for $60 \mathrm{~min}$ to detect a 284 base pair product size of the $i n v A$ target gene. Furthermore, the iro $B$ gene that is unique to $S$. enterica species was used to confirm the identity of the species. The primers used are presented in Table 1 and everything was done following the same procedure used for inv $A$ gene amplification, except for the annealing temperature, which in this case was $55^{\circ} \mathrm{C}$ for $40 \mathrm{~s}$.

\section{Detection of virulence genes}

The primers used to detect virulence genes are depicted in Table 2. The PCR reactions was carried out in a total volume of $25 \mu \mathrm{L}$ and under the following conditions: spiC gene (initial denaturation at $94^{\circ} \mathrm{C}$ for $12 \mathrm{~min}, 1 \mathrm{~min}$ of denaturation at $94{ }^{\circ} \mathrm{C}, 30 \mathrm{~s}$ of annealing at $54^{\circ} \mathrm{C}$ and $5 \mathrm{~min}$ of extension at $72{ }^{\circ} \mathrm{C}$ for a total of 34 cycles; $5 \mathrm{~s}$ were added to the extension time each cycle); misL and orfL genes $\left(3 \mathrm{~min}\right.$ at $94{ }^{\circ} \mathrm{C}$, 35 cycles of $1 \mathrm{~min}$ at $94^{\circ} \mathrm{C}, 1 \mathrm{~min}$ at $58^{\circ} \mathrm{C}$ and $1 \mathrm{~min}$ at $72{ }^{\circ} \mathrm{C}$ and finally $5 \mathrm{~min}$ at $72{ }^{\circ} \mathrm{C}$ ) and for pipD gene $\left(94{ }^{\circ} \mathrm{C}\right.$ for $5 \mathrm{~min}, 34$ cycles of $25 \mathrm{~s}$ of denaturation at $94{ }^{\circ} \mathrm{C}, 30 \mathrm{~s}$ of annealing at $56^{\circ} \mathrm{C}$ and $50 \mathrm{~s}$ of extension at $72{ }^{\circ} \mathrm{C}$ and a final cycle at $5 \mathrm{~min}$ at $72{ }^{\circ} \mathrm{C}$ ). Gel electrophoresis of amplified products was then carried out in $1.5 \%$ agarose in a $1 \mathrm{X} \mathrm{TBE}$ buffer containing GelRed. After the gels were run, PCR products were visualised using the ChemiDoc ${ }^{\mathrm{TM}}$ imaging system.

TABLE 1: Primers used to confirm Salmonella spp.

\begin{tabular}{llcl}
\hline Target gene & Primer sequence $\left(\mathbf{5}^{\prime} \rightarrow \mathbf{3}^{\prime}\right)$ & Product size $(\mathbf{b p})$ & Reference \\
\hline invA $^{\text {a }}$ & F:TCATCGCACCGTCAAAGGAACC & 284 & $\begin{array}{l}\text { Li et al. } \\
\text { R:GTGAAATTATCGCCACGTTCGGGCAA }\end{array}$ \\
& F:TGC GTA TTC TGT TTG TCG GTCC & 606 & $\begin{array}{l}\text { Baumler } \\
\text { et al. (1997) }\end{array}$ \\
${\text { iro } B^{\text {b }}}^{\text {R:TAC GTT CCC ACC ATT CTT CCC }}$ & & \\
\hline
\end{tabular}

Note: Please see the full reference list of the article, Zishiri, O.T., Mkhize, N. \& Mukaratirwa, S. 2016, 'Prevalence of virulence and antimicrobial resistance genes in Salmonella spp. isolated from commercial chickens and human clinical isolates from South Africa and Brazil', Onderstepoort Journal of Veterinary Research 83(1), a1067. http://dx.doi.org/10.4102/ojvr. v83i1.1067, for more information.

a, used to confirm all Salmonella spp.

b, used to confirm Salmonella enterica. 
TABLE 2: Primers used to detect virulence genes in Salmonella spp.

\begin{tabular}{llccl}
\hline Target gene & Primer sequence $\left(5^{\prime} \rightarrow \mathbf{3}^{\prime}\right)$ & Size $(\mathbf{b p})$ & Annealing temperature & Mechanism of resistance \\
\hline spiC & $\begin{array}{l}\text { F:CCTGGATAATGACTATTGAT } \\
\text { R:AGTTATGGTGATTGCGTAT }\end{array}$ & 309 & 54 & Type III secretion system \\
misL & $\begin{array}{l}\text { F:GTCGGCGAATGCCGCGAATA } \\
\text { R:GCGCTGTTACGCTAATAGT }\end{array}$ & 400 & 60 & Involved in intramacrophage survival \\
orfL & $\begin{array}{l}\text { F:GGAGTATCGATAAAGATGTT } \\
\text { R:GCGCGTAACGTCAGAATCAA }\end{array}$ & 550 & 60 & Survival in macrophages \\
pipD & $\begin{array}{l}\text { F:CGGCGTTCATGACTTTGAT } \\
\text { R:CGTTATCATTCGGATCGTAA }\end{array}$ & 350 & 56 & $\begin{array}{l}\text { Type III secretion effector associated } \\
\text { with SPl-1 system }\end{array}$ \\
\hline
\end{tabular}

Source: Hughes, L.A., Shopland, S., Wigley, P., Bradon, H., Leatherbarrow, A.H., Williams, N.J. et al., 2008, 'Characterisation of Salmonella enterica serotype Typhimurium isolates from wild birds in northern England from 2005-2006', Journal of Infectious Disease in Developing Countries 4, 4. http://dx.doi.org/10.1186/1746-6148-4-4

\section{Antimicrobial susceptibility testing}

Antimicrobial resistance of the 146 Salmonella isolates were tested against ten antimicrobial agents using the KirbyBauer disc diffusion method on Mueller Hinton Agar following the guidelines of the Clinical and Laboratory standards Institute (CLSI) (CLSI 2008). The antimicrobials selected were those commonly used in the poultry industry, namely gentamicin $(10 \mu \mathrm{g})$, amoxicillin $(10 \mu \mathrm{g})$, erythromycin (10 $\mu \mathrm{g})$, chloramphenicol $(30 \mu \mathrm{g})$, tetracycline $(10 \mu \mathrm{g})$, trimethoprim $(1.25 \mu \mathrm{g})$, ampicillin $(10 \mu \mathrm{g})$, streptomycin $(25 \mu \mathrm{g})$, trimethoprim-sulfamthoxazole $(25 \mu \mathrm{g})$ and kanamycin $(30 \mu \mathrm{g})$. The Oxoid antibiotic discs were impregnated with the concentrations of each antibiotic. First, Mueller Hinton Agar was inoculated with $0.1 \mathrm{~mL}$ of nutrient broth samples, which had been inoculated with a loopful of glycerol stocks of positive samples and then incubated at $37^{\circ} \mathrm{C}$ for $24 \mathrm{~h}$. With the use of a glass hockey stick, the culture was spread onto the agar for even distribution of the organisms that demonstrated the presence of Salmonella after PCR, thereafter; discs impregnated with antibiotics were evenly placed on plates and then incubated at $37^{\circ} \mathrm{C}$ for $24 \mathrm{~h}$. The inhibition zones were measured and scored as sensitive (S), intermediate susceptibility (I) and resistant (R) according to the CLSI recommendations. Escherichia coli ATCC 25922 was used as a reference strain for antibiotic disc control (Bacci et al. 2012).

\section{Detection of antimicrobial resistance genes}

Genomic DNA of Salmonella extracted was used to detect antimicrobial resistance genes. The primer sets used to detect antimicrobial resistance genes are presented in Table 3. The PCR reactions were carried out in total volumes of $25 \mu \mathrm{L}$ each using the following conditions: pse-1 gene (initial denaturation at $94{ }^{\circ} \mathrm{C}$ for $12 \mathrm{~min}, 1 \mathrm{~min}$ of denaturation at
$94{ }^{\circ} \mathrm{C}, 30 \mathrm{~s}$ of annealing at $57^{\circ} \mathrm{C}$ and $5 \mathrm{~min}$ of extension at $72{ }^{\circ} \mathrm{C}$ for a total of 34 cycles; $5 \mathrm{~s}$ was added to the extension time each cycle); ant ( $\left.3^{\prime \prime}\right)$-la gene ( 3 min at $94^{\circ} \mathrm{C}$, 35 cycles of $1 \mathrm{~min}$ at $94^{\circ} \mathrm{C}, 1 \mathrm{~min}$ at $58^{\circ} \mathrm{C}$ and $1 \mathrm{~min}$ at $72{ }^{\circ} \mathrm{C}$ and finally $5 \mathrm{~min}$ at $\left.72^{\circ} \mathrm{C}\right)$; tet $A$ and tet $B$ gene $\left(94^{\circ} \mathrm{C}\right.$ for $5 \mathrm{~min}, 34$ cycles of $25 \mathrm{~s}$ of denaturation at $94{ }^{\circ} \mathrm{C}, 30 \mathrm{~s}$ of annealing at $55^{\circ} \mathrm{C}$ and $50 \mathrm{~s}$ of extension at $72{ }^{\circ} \mathrm{C}$ and a final cycle at $5 \mathrm{~min}$ at $72{ }^{\circ} \mathrm{C}$ ). Sul1 and sul2 detection was carried in the same way as for tetracycline genes, but with annealing temperatures of $65^{\circ} \mathrm{C}$ and $52{ }^{\circ} \mathrm{C}$ respectively. Gel electrophoresis of the amplified products was then carried out in $1.5 \%$ agarose in a $1 \mathrm{X}$ TBE buffer containing GelRed. After the gels were run, the PCR products were visualised using the ChemiDocTM imaging system.

\section{Ethical approval}

The animal studies were approved by the appropriate ethics committee of the University of KwaZulu-Natal (Reference: 012/15/Animal); therefore, they have been performed in accordance with the ethical standards laid down in the 1964 Declaration of Helsinki and its later amendments.

\section{Results}

\section{Culture identification}

Out of the 200 samples collected from SABC slaughterhouses, only $102(51 \%)$ were confirmed positive for Salmonella. The 102 Salmonella isolates together with the 24 Salmonella isolates from Brazilian chickens (BBC) and 20 human clinical isolates (SAHC) obtained from National Health Laboratory Service (NHLS) made the total of samples used in this study 146. Out of the 146 samples screened for the iroB gene, most were confirmed to be Salmonella enterica with the following prevalence rates: 17 (85\%) of human clinical samples,

TABLE 3: Primers used to screen antimicrobial resistance genes in Salmonella spp.

\begin{tabular}{|c|c|c|c|c|c|}
\hline Antimicrobial agent & Target gene & Primer sequence $\left(5^{\prime}-3^{\prime}\right)$ & Size (bp) & References & Mechanism of resistance \\
\hline Ampicillin & pse-1 & $\begin{array}{l}\text { F:CGCTTCCCGTTAACAAGTAC } \\
\text { R:CTGGTTCATTTCAGATAGCG }\end{array}$ & 419 & Bacci et al. (2012) & - \\
\hline Gentamicin & ant (3")-la & $\begin{array}{l}\text { F:GTGGATGGCGGCCTGAAGCC } \\
\text { R:ATTGCCCAGTCGGCAGCG }\end{array}$ & 526 & Bacci et al. (2012) & $\begin{array}{l}\text { Aminoglycoside } \\
\text { adenyltransferase }\end{array}$ \\
\hline \multirow[t]{2}{*}{ Tetracycline } & tet $A$ & $\begin{array}{l}\text { F:GCTACATCCTGCTTGCCTTC } \\
\text { R:CATAGATCGCCGTGAAGAGG }\end{array}$ & 210 & Bacci et al. (2012) & Efflux \\
\hline & tet $B$ & $\begin{array}{l}\text { F:TTGGTTAGGGGCAAGTTTTG } \\
\text { R:GTAATGGGCCAATAACACCG }\end{array}$ & 659 & Bacci et al. (2012) & Efflux \\
\hline \multirow[t]{2}{*}{ Sulfamethoxazole } & Sul 1 & $\begin{array}{l}\text { F:GCG CGG CGT GGG CTA CCT } \\
\text { R:GATTTCCGCGACACCGAGACAA }\end{array}$ & 350 & Poppe et al. (2006) & $\begin{array}{l}\text { Dihydropteroate synthase } \\
\text { inhibitor }\end{array}$ \\
\hline & Sul 2 & $\begin{array}{l}\text { F:CGG CAT CGT CAA CAT AACC } \\
\text { R:GTG TGC GGA TGA AGT CAG }\end{array}$ & 720 & Poppe et al. (2006) & $\begin{array}{l}\text { Dihydropteroate synthase } \\
\text { inhibitor }\end{array}$ \\
\hline
\end{tabular}


70 (68.6\%) of South African chicken samples and 17 (70.8\%) of Brazilian chicken samples. Figures 1 and 2 illustrate the amplification PCR products for invA and iro $B$ gene respectively.

\section{Detection of virulence genes in Salmonella spp.}

PCR was used to screen for all four virulence genes and all the genes screened were depicted in Figures 3, 4, 5 and 6. All the amplicon sizes were consistent with the sizes that were expected. Table 4 shows that spiC (47\%), pipD (35\%), misL $(2 \%)$ and orfL $(20.6 \%)$ genes were harboured in South African broiler chicken isolates. It was also demonstrated that

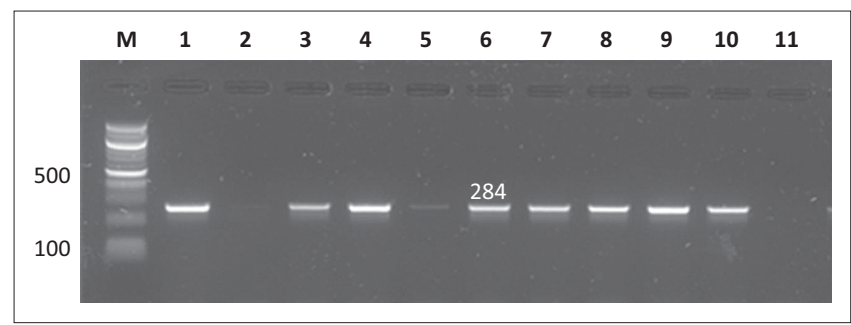

Lane M, 100 bp marker; lane 1-9, test samples; lane 10, positive control; lane 11, negative control.

FIGURE 1: Detection of the $284 \mathrm{bp}$ invA gene amplicon from eight representative Salmonella isolates by agarose gel electrophoresis.

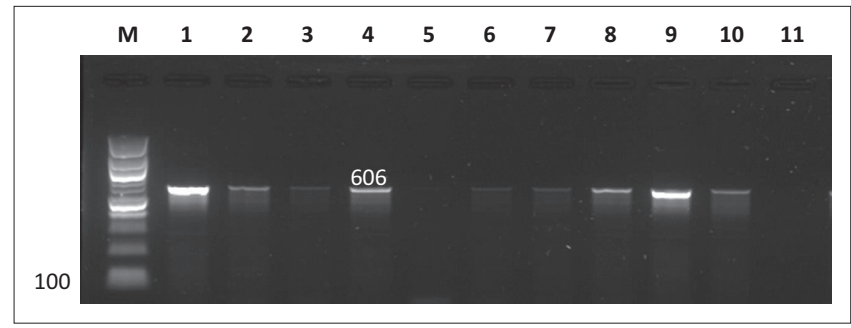

Lane M, 100 bp marker; lane 1-9, test samples; lane 10, positive control; lane 11, negative control.

FIGURE 2: Detection of the 606 bp iroB gene amplicon from nine representative Salmonella isolates by agarose gel electrophoresis.

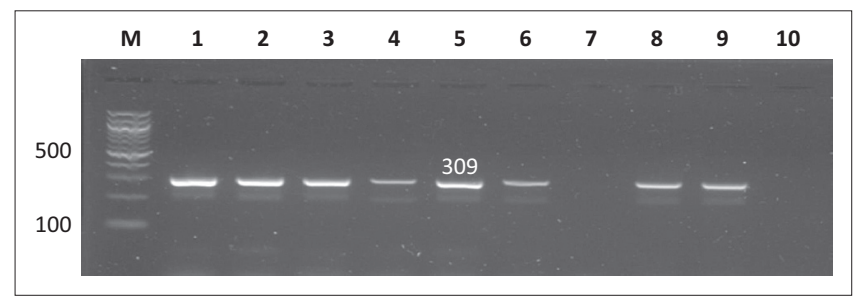

Lane M, 100 bp marker; lane 1-9, test samples; lane 10, negative control.

FIGURE 3: Detection of the $309 \mathrm{bp}$ spiC gene amplicon from eight representative Salmonella isolates by agarose gel electrophoresis.

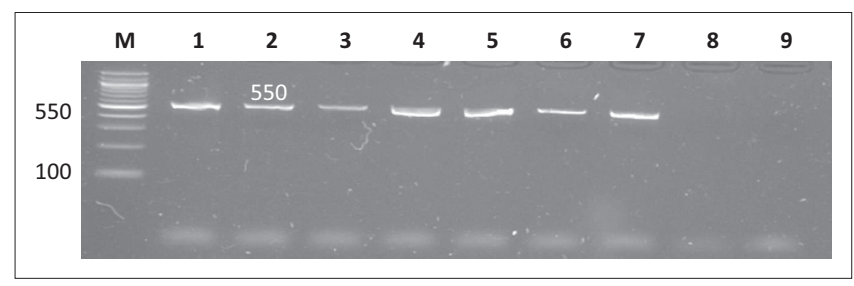

Lane M, 100 bp marker; lane 1-8, test samples; lane 9, negative control.

FIGURE 4: Detection of the $550 \mathrm{bp}$ mis $L$ gene amplicon from seven representative Salmonella isolates by agarose gel electrophoresis.

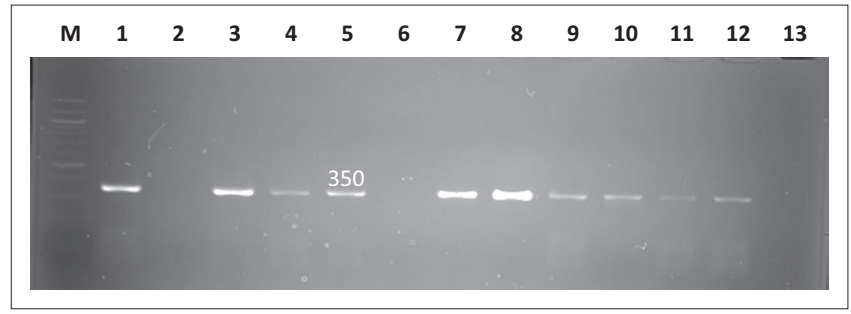

Lane M, 100 bp marker; lane 1-12, test samples; lane 13, negative control.

FIGURE 5: Detection of the 350 bp orfL gene amplicon from nine representative Salmonella isolates by agarose gel electrophoresis.

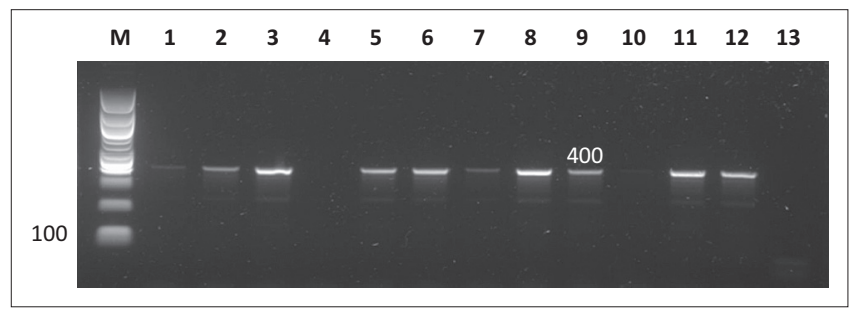

Lane M, 100 bp marker; lane 1-12, test samples; lane 13, negative control.

FIGURE 6: Detection of the $400 \mathrm{bp}$ pipD gene amplicon from nine representative Salmonella isolates by agarose gel electrophoresis.

Brazilian broiler Salmonella isolates harboured all the genes, with the following prevalence rates: spiC (83\%), pipD (87.5\%), misL $(29 \%)$ and orfL (25\%). The same table presents the results for South African human clinical isolates that were harbouring $85 \%$ of spiC gene, followed by pipD (80\%), then misL (75\%), and lastly $20 \%$ of orfL.

\section{Antimicrobial susceptibility testing}

A total of 146 Salmonella isolates from different origins were tested for resistance to ten antimicrobial agents using the disc diffusion method. The incidences of resistance for all the isolates tested are presented in Table 5. Salmonella isolated from SABC exhibited resistance to all ten antimicrobials and the highest rates of resistance observed were: tetracycline $(93 \%)$, trimethoprim-sulfamthoxazole $(84 \%)$, trimethoprim $(78.4 \%)$, kanamycin $(74 \%)$, gentamicin $(48 \%)$, ampicillin $(47 \%)$, amoxicillin and chloramphenicol (31\%), erythromycin (18\%) and streptomycin (12\%). Isolates from Brazilian broiler chickens also demonstrated resistance to all antimicrobials tested and $100 \%$ of the isolates exhibited complete resistance to ampicillin, amoxicillin and tetracycline $(83 \%)$, trimethoprim $(66.7 \%)$, erythromycin $(62.5 \%)$, trimethoprim-sulfamthoxazole $(50 \%)$, kanamycin $(16.7 \%)$, gentamicin and streptomycin (12.5\%) and chloramphenicol (4.2\%). Salmonella isolates from South African human clinical isolates exhibited resistance to eight antimicrobial agents. The highest resistance rates were observed for erythromycin and amoxicillin, both at $30 \%$. Multidrug resistance was also observed across all isolates tested and Table 6 summarises the resistance patterns of Salmonella isolates in the current study. The resistance patterns provide evidence for multidrug resistance and from Table 6 it can be seen that the Salmonella isolates used have the potential to confer resistance to more than two antimicrobial agents. 
TABLE 4: Prevalence of virulence genes in Salmonella isolates from three different origins.

\begin{tabular}{|c|c|c|c|c|c|c|c|c|c|c|c|c|c|}
\hline \multirow[t]{2}{*}{ Origin } & \multicolumn{13}{|c|}{ Virulence genes } \\
\hline & Number of isolates $(n)$ & invA & $\%$ & $\operatorname{sipC}$ & $\%$ & pipD & $\%$ & misL & $\%$ & orfL & $\%$ & iroB & $\%$ \\
\hline$S A B C$ & 102 & 102 & 100 & 48 & 47 & 36 & 35 & 2 & 2 & 21 & 20.6 & 70 & 68.6 \\
\hline BBC & 24 & 24 & 100 & 20 & 83 & 21 & 87.5 & 7 & 29 & 6 & 25 & 17 & 70.8 \\
\hline SAHC & 20 & 20 & 100 & 17 & 85 & 16 & 80 & 15 & 75 & 10 & 20 & 17 & 85 \\
\hline Total & 146 & 146 & 100 & 85 & 58 & 73 & 50 & 24 & 16 & 37 & 25 & 104 & 71.2 \\
\hline
\end{tabular}

SABC, South African broiler chicken isolates; BBC, Brazilian broiler chicken isolates; SAHC, South African human clinical isolates.

TABLE 5: Antimicrobial susceptibility tests on Salmonella isolates of different origins.

\begin{tabular}{|c|c|c|c|c|c|c|c|c|c|c|c|c|c|c|c|c|c|c|}
\hline \multirow[t]{3}{*}{ Antibiotics } & \multicolumn{18}{|c|}{ Number of isolates } \\
\hline & \multicolumn{6}{|c|}{$\mathrm{SABC} \uparrow$} & \multicolumn{6}{|c|}{$\mathrm{BBC}+$} & \multicolumn{6}{|c|}{ SAHC§ } \\
\hline & $\mathbf{R}$ & $\%$ & 1 & $\%$ & $S$ & $\%$ & $\mathbf{R}$ & $\%$ & 1 & $\%$ & $S$ & $\%$ & $\mathbf{R}$ & $\%$ & 1 & $\%$ & $S$ & $\%$ \\
\hline AMP & 48 & 47.0 & 41 & 40.0 & 13 & 13.0 & 24 & 100.0 & 0 & 0.0 & 0 & 0.0 & 3 & 15 & 8 & 40 & 9 & 45 \\
\hline AML & 32 & 31.0 & 45 & 44.0 & 25 & 25.0 & 20 & 83.0 & 3 & 12.5 & 1 & 4.2 & 6 & 30 & 5 & 25 & 9 & 45 \\
\hline C & 32 & 31.0 & 30 & 29.0 & 40 & 39.0 & 1 & 4.2 & 2 & 8.3 & 21 & 88.0 & 0 & 0 & 1 & 5 & 19 & 95 \\
\hline $\mathrm{CN}$ & 49 & 48.0 & 26 & 26.0 & 27 & 26.5 & 3 & 12.5 & 3 & 12.5 & 18 & 75.0 & 0 & 0 & 0 & 0 & 20 & 100 \\
\hline$E$ & 18 & 18.0 & 13 & 13.0 & 71 & 69.6 & 15 & 62.5 & 6 & 25.0 & 3 & 12.5 & 6 & 30 & 10 & 50 & 4 & 20 \\
\hline $\mathrm{K}$ & 75 & 74.0 & 9 & 9.0 & 18 & 18.0 & 4 & 16.7 & 0 & 0.0 & 20 & 83.0 & 1 & 5 & 0 & 0 & 19 & 95 \\
\hline$S$ & 12 & 12.0 & 8 & 8.0 & 82 & 80.0 & 3 & 12.5 & 15 & 62.5 & 6 & 25.0 & 4 & 20 & 3 & 15 & 13 & 65 \\
\hline SXT & 86 & 84.3 & 0 & 0.0 & 16 & 15.7 & 12 & 50.0 & 4 & 16.7 & 8 & 33.0 & 3 & 15 & 0 & 0 & 17 & 85 \\
\hline TE & 95 & 93.0 & 7 & 7.0 & 0 & 0.0 & 20 & 83.0 & 0 & 0.0 & 4 & 16.7 & 2 & 10 & 1 & 50 & 17 & 85 \\
\hline W & 80 & 78.4 & 4 & 3.9 & 19 & 18.6 & 16 & 66.7 & 3 & 12.5 & 5 & 20.8 & 4 & 20 & 2 & 10 & 14 & 70 \\
\hline
\end{tabular}

AMP, ampicillin; AML, amoxicillin; C, chloramphenicol; CN, gentamicin; E, erythromycin; K, kanamycin; S, streptomycin; STX, trimethoprim-sulfamthoxazole; TE, tetracycline; W, trimethoprim; SABC South African broiler chicken isolates; BBC, Brazilian broiler chicken isolates; SAHC, South African human clinical isolates; R, Resistant; I, Intermediate susceptibility; S, Susceptible.

$\dagger, n=102 ; \vdots, n=24 ; \S, n=20$.

TABLE 6: Antibiotic resistance patterns of Salmonella isolates illustrating multiple drug resistance.

\begin{tabular}{lcccccc}
\hline $\begin{array}{l}\text { Antibiotic } \\
\text { resistance patterns }\end{array}$ & \multicolumn{7}{c}{ Number of isolates } \\
\cline { 2 - 7 } & SABC & $\%$ & BBC & $\%$ & SAHC & $\%$ \\
\hline AMP, TE & 32 & 31.4 & 20 & 83.0 & 1 & 5 \\
AML, TE & 31 & 30.4 & 16 & 66.7 & 2 & 10 \\
TE, W & 74 & 72.5 & 14 & 58.0 & 1 & 5 \\
S, TE & 12 & 11.8 & 3 & 12.5 & 0 & 0 \\
K, TE & 71 & 69.6 & 3 & 12.5 & 0 & 0 \\
SXT, TE & 69 & 67.6 & 10 & 41.7 & 0 & 0 \\
E, TE & 14 & 13.7 & 12 & 50.0 & 2 & 10 \\
C, TE & 19 & 18.6 & 1 & 4.2 & 0 & 0 \\
AMP, AML, TE & 30 & 25.0 & 16 & 80.0 & 1 & 5 \\
AMP, C, TE & 10 & 9.8 & 1 & 4.2 & 0 & 0 \\
E, W & 18 & 17.6 & 12 & 50.0 & 4 & 20 \\
E, SXT, W & 15 & 14.7 & 9 & 37.5 & 1 & 5 \\
S, SXT, W & 11 & 10.8 & 3 & 12.5 & 0 & 0 \\
TE, W & 74 & 72.4 & 14 & 58.0 & 1 & 5 \\
AML, AMP, TE, W & 23 & 22.5 & 12 & 50.0 & 0 & 0 \\
AML, AMP, E, TE & 12 & 11.8 & 10 & 41.7 & 0 & 0 \\
\hline A & &
\end{tabular}

AMP, ampicillin; AML, amoxicillin; C, chloramphenicol; $C N$, gentamicin; $E$, erythromycin; $\mathrm{K}$, kanamycin; S, streptomycin; STX, trimethoprim-sulfamthoxazole; TE, tetracycline; W, trimethoprim; SABC, South African broiler chicken isolates; BBC, Brazilian broiler chicken isolates; SAHC, South African human clinical isolates.

\section{Molecular detection of antimicrobial resistance genes in Salmonella}

Antimicrobial resistance genes were detected in all 146 Salmonella isolates, regardless of antimicrobial susceptibility, using the disc diffusion method since this method is presumptive and needs to be supplemented with other tests. Observed PCR results indicated that detected Salmonella contained antimicrobial resistance genes known to confer resistance. Six antimicrobial resistance genes were screened in total: pse-1, ant (3")-la, tet $A$, tet $B$, sul 1 and sul 2; the phenotypes of the genes are illustrated in Figures $7,8,9,10$, 11 and 12 respectively. The prevalence rates of the genes

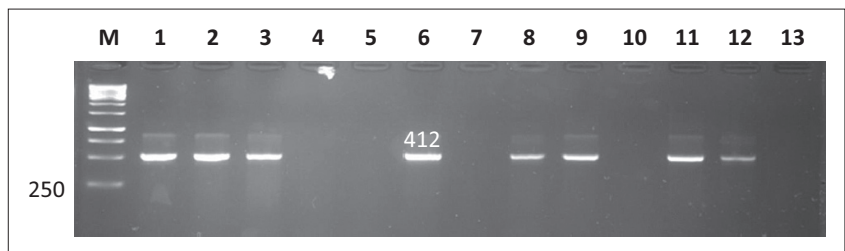

Lane M, 250 bp marker; lane 1-12, test samples; lane 13, negative control. FIGURE 7: Detection of the 412 bp pse-1 gene amplicon from eight representative Salmonella isolates by agarose gel electrophoresis.

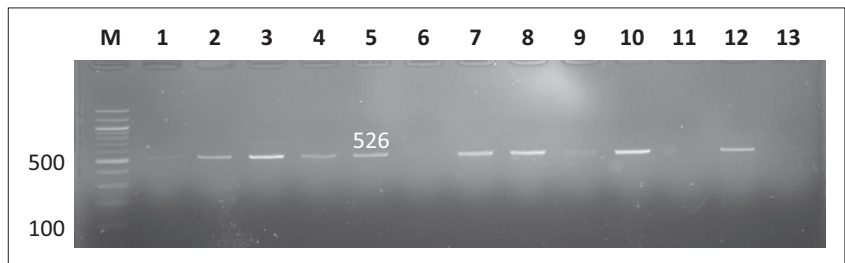

Lane M, 100 bp marker; lane 1-12, test samples; lane 13, negative control.

FIGURE 8: Detection of the 526 bp ant (3")-la gene amplicon from eight representative Salmonella isolates by agarose gel electrophoresis.

detected are presented in Table 7. In the SABC isolates the most prevalent antimicrobial resistance gene that was detected was pse-1 gene (56\%), known to confer resistance to ampicillin. This gene was followed by tet $A(44 \%)$, ant (3")-la $(32 \%)$ and tet $B(28 \%)$, known to confer resistance to tetracycline, gentamicin and tetracycline respectively as depicted in Table 7. In the Brazilian broiler chicken isolates tet $A$ and sul 1 genes (83\%) were the most prevalent genes, followed by sul $2(79 \%)$, ant (3")-la (75\%), pse-1 (63\%) and tet $B(33 \%)$. Finally, in the South African human isolates the gene that showed the highest prevalence was ant (3")-la (80\%), followed by tet $A(70 \%)$. The tet B, sul 1 and sul 2 genes all exhibited $60 \%$ prevalence and lastly, the $p s e-1$ gene reported a $(50 \%)$ prevalence. These results are partially 


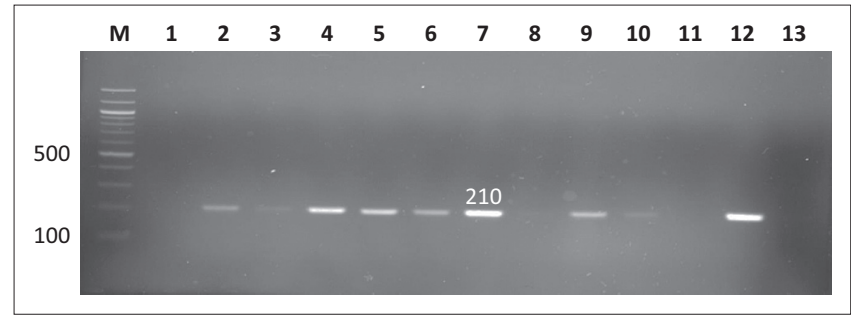

Lane M, 100 bp marker; lane 1-12, test samples; lane 13, negative control.

FIGURE 9: Detection of the $210 \mathrm{bp}$ tet $A$ gene amplicon from seven representative Salmonella isolates by agarose gel electrophoresis.

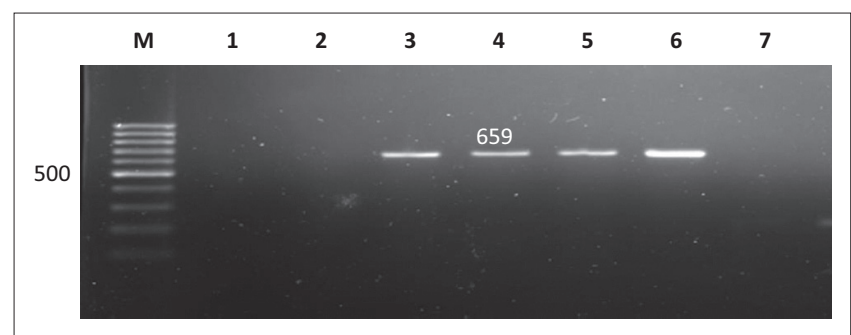

Lane M, 100 bp marker; lane 1-6, test samples; lane 7, negative control.

FIGURE 10: Detection of the 659 bp tet $B$ gene amplicon from four representative Salmonella isolates by agarose gel electrophoresis.

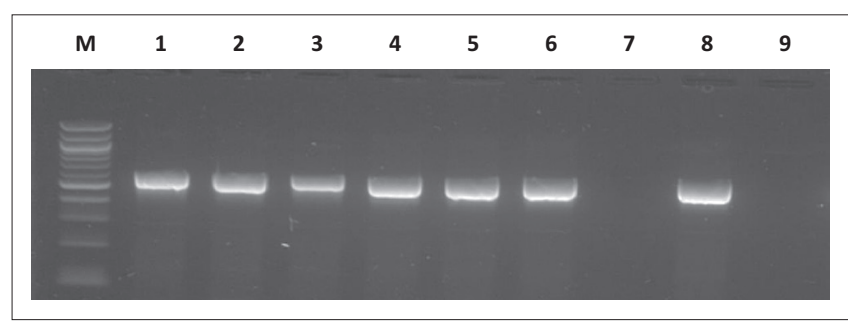

Lane M, 50 bp marker; lane 1-8, test samples; lane 9, negative control.

FIGURE 11: Detection of the $350 \mathrm{bp}$ sul 1 gene amplicon from seven representative Salmonella isolates by agarose gel electrophoresis.

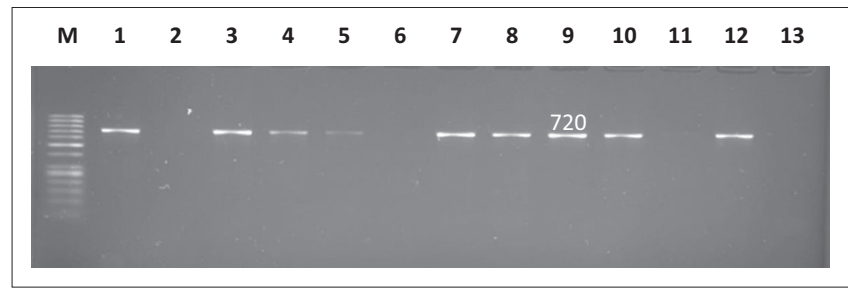

Lane M, 100 bp marker; lane 1-12, test samples; lane 13, negative control.

FIGURE 12: Detection of the 720 bp sul 2 gene amplicon from eight representative Salmonella isolates by agarose gel electrophoresis.

TABLE 7: Prevalence of antimicrobial resistance genes screened from 146 Salmonella isolates.

\begin{tabular}{llcccccc}
\hline Antibiotics & $\begin{array}{l}\text { Resistance } \\
\text { genes }\end{array}$ & \multicolumn{6}{c}{ Number of isolates } \\
\cline { 3 - 8 } & & SABC $\dagger$ & $\%$ & BBC + & $\%$ & SAHC & $\%$ \\
\hline Ampicillin & pse-1 & 57 & 56.0 & 15 & 63 & 10 & 50 \\
Gentamicin & ant (3")-la & 33 & 32.0 & 18 & 75 & 16 & 80 \\
Sulfamethoxazole & sul 1 & 44 & 43.0 & 20 & 83 & 12 & 60 \\
& sul 2 & 43 & 42.0 & 19 & 79 & 12 & 60 \\
& sul 1, sul 2 & 18 & 17.6 & 18 & 75 & 10 & 50 \\
Tetracycline & tet A & 45 & 44.0 & 20 & 83 & 14 & 70 \\
& tet B & 29 & 28.0 & 8 & 33 & 12 & 60 \\
& tet A, tet B & 15 & 14.7 & 6 & 25 & 7 & 35 \\
\hline
\end{tabular}

$\dagger, n=102 ; \ddagger, n=24 ; \S, n=20$. consistent with the antimicrobial susceptibility testing because most of the genes were detected in isolates that exhibited resistance.

\section{Discussion}

The injudicious use of antimicrobials leads to resistance in various bacteria such as Salmonella, and therefore antibiotic resistance in foodborne bacterial enteric pathogens is an almost inevitable consequence of the irrational use of antimicrobial drugs in animal production systems (Newell et al. 2010). Findings from the current study demonstrated the presence of Salmonella in broiler chicken isolates at farm level. Out of the 200 samples tested for Salmonella only 102 (51\%) samples tested positive using PCR, amplifying the inv $A$ gene. These results were almost in agreement with results presented in previous studies (Antunes et al. 2003; Capita, Alonso-Calleja \& Prieto 2007; Chuanchuen \& Padungtod 2009; Hao Van et al. 2007), which reported Salmonella prevalence as 57\%, 49\%, 60\% and 53.3\% respectively. Cortez et al. (2006) conducted a study on the identification of Salmonella isolates from chicken abattoirs and reported that out of 288 samples collected 52 (18\%) samples were tested positive. These results are relatively low and contrary to results obtained from the current study. Moreover, similar previous studies (Dogru et al. 2010; Kaushik et al. 2014; Van Nierop et al. 2005; Zewdu \& Cornelius 2009) also reported very low Salmonella prevalence $-8 \%$, $23.7 \%, 19.2 \%$ and $8 \%$ respectively - compared to the current study. Information from the literature provides proof that broiler chickens are potential carriers of Salmonella. However, various factors contributing to the high prevalence of Salmonella isolates were detected in the present study. Feed, housing and the hygiene status of the farms where the chickens were reared may be some of the factors. The presence of Salmonella species at farm level is a serious concern because it shows that the potential exists for the pathogens to disseminate from the farms to communities. This is of great concern because the majority of South Africans depend on food sold in informal retail outlets where hygienic conditions are questionable and promote the accumulation and proliferation of pathogens, posing a danger to consumers. The presence of Salmonella in chicken meat is quite serious because South Africa imports a significant amount of poultry products from other countries such as Brazil, China and the USA. Consumers are therefore at risk of contracting salmonellosis from either local or imported poultry products.

It is worth noting that the greatest attribute Salmonella uses to survive in a host cell is pathogenicity. Various studies have probed the significance of pathogenicity in a pathogen-host interaction and most concluded that pathogenicity is indeed significant for the pathogen to survive and proliferate. Pathogenicity helps Salmonella to invade and destroy epithelial cells in the host intestines (Uchiya \& Nikai 2008) and then to colonise other cell lines. All this happens as a result of the presence of the genetic determinants responsible for virulence in Salmonella spp. 
In the current study the prevalence of four virulence genes was established. The virulence genes were selected on the basis of their functions and danger to chickens and humans. All the genes detected belonged to different Salmonella pathogenicity islands (SP1). It was not part of the scope of the study to detect these islands, but the information was sourced from the literature. Salmonella pathogenicity islands SP1-2, SP1-5, SP1-3 and SP1-4 encode for spiC, pipD, misL and orfL genes respectively.

The function of the spiC gene is to interact with intercellular membrane trafficking in such a manner as to alter it, hindering the correct cellular functioning (Uchiya \& Nikai 2008). The results obtained from South African broiler chickens present spiC gene as the most prevalent virulent gene that was detected among the four genes that were screened. The prevalence rates reported were $47 \%, 35 \%, 2 \%$, and $20.6 \%$, all of them corresponding to the following genes respectively: spiC, pipD, misL and orfL. The detection of these genes in isolates obtained at a farm level on the carcasses of healthy chickens emphasises the fact that healthy chickens with no sign of illness can be carriers of pathogenic Salmonella (Skyberg, Logue \& Nolan 2006). This demonstrates the risk of chicken meat to consumers and implies the possible dissemination of virulence genes.

The presence of the same virulence genes in human clinical samples demonstrates the dissemination and distribution of virulence genes, although the origin of the Salmonella that infected the patients was not known because no background information had been obtained from patients about possible sources of infection with Salmonella. Salmonella isolates detected from Brazilian imported chicken meat also demonstrated the presence of all the virulence genes screened during the study, with spiC and pipD genes as the most prevalent, having a prevalence rate of $83 \%$ and $87 \%$ respectively. The genes with the lowest prevalence rates were orfL (25\%) and misL (29\%); both have been reported to be responsible for the survival of Salmonella in host macrophages.

Virulence genes have also been detected in previous studies from Brazil (Borges et al. 2013; Castilla et al. 2006; Dias de Olivieira et al. 2003), West Africa (Dione et al. 2011), Colombia (Sánchez-Jiménez et al. 2010) and England (Hughes et al. 2008). Therefore, the detection of virulence genes from chicken meat imported from other countries and then sold in South Africa indicates the possibility of a transfer of Salmonella pathogenic strains from other countries to South Africa. Although virulence genes are common in local Salmonella strains, receiving foreign strains can worsen the situation by increasing the prevalence of genes encoding for pathogenicity and increasing genetic diversity of Salmonella strains in South Africa.

Antimicrobial resistance is a global public health problem. The increasing antimicrobial resistance in Salmonella is a forward irreversible reaction, but it can be reduced if certain precautions are followed worldwide. Tetracycline is a commonly used antimicrobial agent in human and animal medicine because it is cheap and easily accessible. Tetracycline resistance has been reported worldwide, and it comprises three types of resistance mechanism, namely tetracycline efflux, tetracycline modification and ribosomal protection (Roberts 2005). During the current study Salmonella isolates from Brazilian chicken isolates, South African chicken isolates and South African human isolates exhibited resistance to tetracycline, with prevalence rates of $83 \%, 93 \%$ and $10 \%$ respectively. Both genes known to confer resistance to tetracycline, namely tet $A$ and tet $B$, were detected in some isolates that exhibited resistance. The prevalence of tet $A$ was higher than tet $B$ in all the groups of isolates screened. This was quite similar to the findings in previous studies that reported the same pattern (Chuanchuen \& Padungtod 2009; Miko et al. 2005). Not all of the confirmed Salmonella isolates were harbouring tet $A$ and tet $B$ genes, leading to the prevalence of the genes being low compared to the prevalence of Salmonella resistance to tetracycline.

These results imply that there might be other antimicrobial genes conferring resistance that were not detected in the study, as there are other determinants that confer resistance to tetracycline, namely tet $C$, tet $D$, tet $R$, tet $M$ and several others. However, in the human isolates the prevalence of resistance was very low, but the two genes were detected even in the isolates that were susceptible to tetracycline.

Ampicillins and amoxicillin are among the drugs of choice for treating salmonellosis (De Toro et al. 2011). In the current study, Salmonella isolates from Brazilian chickens demonstrated high resistance to these two drugs compared to other isolates. A gene conferring resistance to $\beta$-lactamase, namely pse-1, was detected in most of the Salmonella isolates found to be resistant to ampicillin and amoxicillin. Llanes, Kirchgesner and Plesiat (1999) reported that resistance to $\beta$-lactam is due to the production of the pse- 1 enzyme. According to Glenn et al. (2011), Salmonella spp. isolated from food-producing animals have been reported to carry the pse-1 gene and it is one of the most prevalent $\beta$-lactamases.

The current study demonstrated high prevalence of Salmonella isolates with the $p s e-1$ gene compared to similar studies (Bacci et al. 2012; Chuanchuen \& Padungtod 2009) that reported very low prevalence rates of $0 \%$ and $5 \%$ respectively. South African studies have detected the presence of pse-1 gene in aquatic systems and in livestock production (Igbinosa 2015; Igbinosa \& Okoh 2012). Although studies related to the mapping pse-1 gene have been conducted, there is still a paucity of information on the prevalence of this gene in South Africa. More information on such genes can contribute to the solution of developing new drugs. Since high prevalence rates of $p s e-1$ gene were observed, this implies that the presence of $\beta$-lactamase in foodborne pathogens is increasing. Batchelor, Hopkins and Threlfall (2005) speculated that the increasing presence of $\beta$-lactamase in pathogenic bacteria limits the therapeutic use of antimicrobial agents. The ant (3")-la gene is 
one of the aminoglycoside resistance determinants. It has been detected in a number of bacterial pathogens, but information about this gene's prevalence in Salmonella is limited, especially in Africa, where little research has been done. In the current study it was detected in some of the gentamicin-resistant Salmonella isolates. Moreover, genes conferring resistance to sulfamethoxazole (sul 1 and sul 2) were also detected in most Salmonella isolates that exhibited resistance to trimethoprim-sulfamethoxazole. The results showed that some isolates were even harbouring both genes.

Multidrug resistance is an increasing problem that has been reported in both animal and human medicine. Salmonella isolates used in the present study illustrated a high rate of multidrug resistance. The results presented in Table 6 show patterns illustrating multidrug resistance, which can be confirmed if an isolate is resistant to more than two antibiotics. There may be several possible explanations for such outcomes but the main one could be a lack of compliance with legislation governing the amount and type of antimicrobial agents used in the South African poultry industry and also in human medicine. Multidrug resistance has a negative impact on therapy in both animal and human medicine. Various studies have proven that infections caused by multidrugresistant Salmonella strains are more dangerous than the infections caused by susceptible strains, since they extensively delay therapy, placing patients' lives at risk (Martin et al. 2004; Varma et al. 2005). The presence of multidrug-resistant Salmonella strains in chickens and also in humans has serious implications for public health systems and for the economy.

Overall, the results obtained from the study demonstrate that the detected Salmonella strains harboured both virulence and antimicrobial resistance genes. The potential exists for the random dissemination of these genes, with negative implications for the health and welfare of chickens and humans and could result in increased antimicrobial resistance. Since some developed and developing countries have prohibited the use of some antimicrobial agents as feed additives in animal husbandry, especially poultry, South Africa should take note of what has been happening in other countries with regard to the regulation of antimicrobial use and attempt to prevent the escalating antibiotic resistance problem.

\section{Conclusion}

In conclusion, all of the 12 genes examined in this study were successfully amplified in the Salmonella isolated from different origins. These findings indicate that the selective pressure caused by the variety of antibiotics administered therapeutically in veterinary practice and poultry production systems for growth promotion and prophylaxis has resulted in an increase in genes conferring resistance to Salmonella. It is difficult to make comparisons between the Salmonella surveillance surveys conducted in different countries as the prevalence of Salmonella varies regionally and isolation rates depend upon the country, sample plan and methodology used. The data from this study indicate the dissemination of antimicrobial resistance genes in Salmonella isolated from broiler chickens at the abattoir level. The emergence and dissemination of antimicrobial-resistant Salmonella in food animals has major public health implications, especially for large-scale suppliers who export their products both regionally and internationally. Therefore, foodborne salmonellosis should constantly be monitored.

Future work in the area of this study should include organism specificity by serotyping positive Salmonella samples in order to determine the serovars of Salmonella which are most prevalent in broiler chickens. Furthermore, phylogenetic analyses should also provide interesting insights into determining how closely related the positive Salmonella isolates are to each other.

\section{Acknowledgements}

The authors would like to acknowledge the College of Agriculture, Engineering and Science as well as the School of Life Sciences at the University of KwaZulu-Natal (Westville Campus) for financial support; NHLS of South Africa for providing the project with isolates from Brazilian broiler chickens and from human clinical isolates. Lastly, we would like to express our most sincere gratitude to the various poultry slaughterhouses within KwaZulu-Natal province in South Africa, who for reasons of confidentiality remain anonymous, for providing the chicken samples for this study.

\section{Competing interests}

The authors declare that they have no financial or personal relationships which may have inappropriately influenced them in writing this article. There is no conflict of interest from all the parties involved in this publication and all parties gave their consent to publish this work.

\section{Authors' contributions}

O.T.Z. was the project leader who was involved in the planning, implementation, execution as well as the monitoring and evaluation of the study. He was also involved in the sampling, most of the molecular genetics laboratory work as well as writing and revising of the manuscript. N.M. was involved in the sampling and bacteriology work as well as the writing of the manuscript. S.M. conceived the idea, gave a great deal of technical advice on all the veterinary aspects and also wrote and revised parts of the manuscript.

\section{References}

Ahmed, A.M. \& Shimamoto, T., 2012, 'Genetic analysis of multiple antimicrobia resistance in Salmonella isolated from diseased broilers in Egypt', Microbiology and Immunology 56, 254-261. http://dx.doi.org/10.1111/j.1348-0421.2012. 00429.x

Amagliani, G., Brandi, G. \& Schiavano, G.F., 2012, 'Incidence and role of Salmonella in seafood safety', Food Research International 45, 780-788. http://dx.doi. org/10.1016/j.foodres.2011.06.022

Antunes, P., Reu, C., Sousa, J.C., Peixe, L. \& Pestana, N., 2003, 'Incidence of Salmonella from poultry products and their susceptibility to antimicrobial agents' International Journal of Food Microbiology 82, 97-103. http://dx.doi.org/10.1016/ S0168-1605(02)00251-9 
Bacci, C., Boni, E., Alpigiani, I., Lanzoni, E., Bonardi, S. \& Brindani, F., 2012, 'Phenotypic and genotypic features of antibiotic resistance in $\mathrm{S}$. enterica isolated from chicken meat and chicken and quail carcasses', International Journal Food Microbiology 160, 16-23. http://dx.doi.org/10.1016/j.jffoodmicro.2012.09.014

Batchelor, M., Hopkins, K.L. \& Threlfall, E.J., 2005, 'Characterization of AmpC mediated resistance in clinical Salmonella isolates recovered from humans during the period 1992 to 2003 in England and Wales', Journal of Clinical Microbiology 43, 2261-2265. http://dx.doi.org/10.1128/JCM.43.5.2261-2265.2005

Baumler, A.J., Heffron, F. \& Reissbrodt, R., 1997, 'Rapid detection of Salmonella enterica with primers specific for iroB', Journal of Clinical Microbiology 35 $1224-1230$

Blanc-Potard, A.B., Solomon, F., Kayser, J. \& Groisman, E.A., 1999, 'The SPI-3 pathogenicity island of Salmonella enterica', Journal of Bacteriology 181 998-1004.

Borges, K.A., Furian, T.Q., Borsoi, A., Moraes, H.L.S., Salle, C.T.P. \& Nascimento, V.P., 2013, 'Detection of virulence-associated genes in Salmonella Enteritidis isolates from chicken in Southern Brazil', Pesquisa Veterinaria Brasileira 33, 1416-1422. http://dx.doi.org/10.1590/\$0100-736X2013001200004

Capita, R., Alonso-Calleja, C. \& Prieto, M., 2007, 'Prevalence of Salmonella enterica serovars and genovars from chicken carcasses in slaughterhouses in Spain' Journal of Applied Microbiology 103, 1366-1375. http://dx.doi.org/10.1111 j.1365-2672.2007.03368.x

Castilla, K.S., Ferreira, C.S.A., Moreno, A.M., Nunes, I.A. \& Ferreira, A.J.P., 2006 'Distribution of virulence genes sefc, pefa and spvc in Salmonella enteritidis phage type 4 strains isolated in Brazil', Brazilian Journal of Microbiology 37, 135-139. http://dx.doi.org/10.1590/S1517-83822006000200007

Centers for Disease Control (CDC), 2013, 'Incidence and trends of infection with pathogens transmitted commonly through food - Foodborne Disease Active Surveillance Network, 10 U.S. Sites, 1996-2012', Weekly Report 62(15), 283-287

Chia, T.W.R., Goulter, R.M., Mcmeekin, T., Dykes, G.A. \& Fegan, N., 2009, 'Attachment of different Salmonella serovars to materials commonly used in a poultry processing plant', Food Microbiology 26, 853-859. http://dx.doi.org/10.1016/j. fm.2009.05.012

Chuanchuen, R. \& Padungtod, P., 2009, 'Antimicrobial resistance genes in Salmonella enterica Isolates from poultry and swine in Thailand', Journal of Veterinary Medical Science 71, 1349-1355. http://dx.doi.org/10.1292/jvms. 001349

CLSI, 2008, Performance standards for antimicrobial disk and dilution susceptibility tests for bacteria isolated from Animals; Approved standard, 3rd edn., CLSI document M31-A3, CLSI, Wayne, PA.

Cogliani, C., Goossens, H. \& Greko, C., 2011, 'Restricting antimicrobial use in food animals: Lessons from Europe', Microbes 6, 274-279. http://dx.doi.org/10.1128/ microbe.6.274.1

Cortez, A.L.L., Carvalho, A.C.F.B., Ikuno, A.A., Bürger, K.P. \& Vidal-Martins, A.M.C., 2006, 'Identification of Salmonella spp. isolates from chicken abattoirs by multiplex-PCR', Research in Veterinary Science 81, 340-344. http://dx.doi. org/10.1016/j.rvsc.2006.03.006

Dallal, M.M.S., Doyle, M.P., Rezadehbashi, M., Dabiri, H., Sanaei, M., Modarresi, S et al., 2010, 'Prevalence and antimicrobial resistance profiles of Salmonella serotypes, Campylobacter and Yersinia spp. isolated from retail chicken and bee Tehran, Iran', Food Control 21, 388-392. http://dx.doi.org/10.1016/j. foodcont.2009.06.001

De Toro, M., Sáenz, Y., Cercenado, E., Rojo-Bezares, B., García-Campello, M Undabeitia, E. et al., 2011, 'Genetic characterization of the mechanisms of resistance to amoxicillin/clavulanate and third-generation cephalosporins in Salmonella enterica from three Spanish hospitals', International Microbiology 14(3), 173-181.

Dias De Olivieira, S.R.C.R., Michael, G.B., Cardoso, M.I.R., Canal, C.W. \& Brandelli, A. 2003, 'Detection of virulence genes in Salmonella enteritidis isolated from different sources', Brazilian Journal of Microbiology 34(1), 123-124. http://dx.doi. org/10.1590/S1517-83822003000500042

Dione, M.M., Ikmapayi, U., Saha, D., Mohammed, I.N., Adegbola, A.R., Geerts, S. et al., 2011, 'Antimicrobial resistance and virulence genes of non-typhoidal Salmonella isolates in the Gambia and Senegal', Journal of Infectious Disease in Developing Countries 5, 765-775.

Dogru, K., Aylin, A., Gencay, N.D. \& Emre, Y., 2010, 'Serotype identification and antimicrobial resistance profiles of Salmonella spp. isolated from chicken carcasses', Tropical Animal Health and Production 42, 893-897. http://dx.doi. org/10.1007/s11250-009-9504-7

Duong, V.N., Paulsen, P., Suriyasathaporn, W., Smulders, F.J., Kyule, M.N., Baumann M.P. et al., 2006, 'Preliminary analysis of tetracycline residues in marketed pork in Hanoi, Vietnam', Annals of the New York Academy of Sciences 1081, 534-542. http://dx.doi.org/10.1196/annals.1373.081

Foley, S.L., Nayak, R., Hanning, I.B., Johnson, T.J, Han, J. \& Ricke, S.C., 2011, 'Population dynamics of Salmonella enterica serotypes in commercial egg and poultry production', Applied Environmental Microbiology 77, 4273-4279. http://dx.doi. org/10.1128/AEM.00598-11

Galan, J.E., Ginocchio, C. \& Costeas, P., 1992, 'Molecular and functional characterization of the Salmonella invasion gene invA: Homology of the invA to members of a new protein family', Journal of Bacteriology 174, 4338-4349.

Glenn, L.M., Lindsey, R.L., Frank, J.F., Meinersmann, R.J., Englen, M.D., Fedorka-Cray, P.J. et al., 2011, 'Analysis of antimicrobial resistance genes detected in multidrug-resistant Salmonella enterica serovar Typhimurium isolated from food animals', Microbial Drug Resistance 17, 407-418. http://dx.doi.org/10.1089/mdr. 2010.0189
Groisman, E.A. \& Ochman, H., 1997, 'How Salmonella became a pathogen', Trends in Microbiology 5, 343-349. http://dx.doi.org/10.1016/S0966-842X (97)01099-8

Gyles, C.L., 2008, 'Antimicrobial resistance in selected bacteria from poultry', Anima Health Review 9, 149-158. http://dx.doi.org/10.1017/S1466252308001552

Hao Van, T.T., Moutais, G., Istivan, T., Thuoc Tran, L. \& Coloei, P.J., 2007, 'Detection of Salmonella spp. in retail raw food samples from Vietnam and characterization of their antibiotic resistance', Applied and Environmental Microbiology 73, 6885-6890. http://dx.doi.org/10.1128/AEM.00972-07

Hersh, D., Monack, D.M., Smith, M.R., Ghori, N., Falkow, S. \& Zychlinsky, A., 1999, 'The Salmonella invasin SipB induces macrophage apoptosis by binding to caspase-1" Proceedings of the National Academy of Science, United States of America 96, 2396-2401. http://dx.doi.org/10.1073/pnas.96.5.2396

Hughes, L.A., Shopland, S., Wigley, P., Bradon, H., Leatherbarrow, A.H., Williams, N.J. et al., 2008, 'Characterisation of Salmonella enterica serotype Typhimurium isolates from wild birds in northern England from 2005-2006', Journal of Infectious Disease in Developing Countries 4, 4. http://dx.doi.org/10.1186/17466148-4-4

Humphrey, T., 2000, 'Public health aspects of Salmonella infection', in C. Wray \& A Wray (eds.), Salmonella in Domestic Animals, pp. 245-262, CABI Publishing, Wallingford.

Igbinosa, I.H., 2015, 'Prevalence and detection of antibiotic-resistant determinant in Salmonella isolated from food-producing animals', Tropical Animal Health and Production 47, 37-43. http://dx.doi.org/10.1007/s11250-014-0680-8

Igbinosa, I.H. \& Okoh, A.I., 2012, 'Antibiotic susceptibility profile of Aeromonas species isolated from wastewater treatment plant', Scientific World Journal 2012:764563. http://dx.doi.org/10.1100/2012/764563

Kaniga, K., Trollinger, D. \& Galan, J.E., 1995, 'Identification of two targets of the type II protein secretion system encoded by the inv and spa loci of Salmonella typhimurium that have homology to the Shigella IpaD and IpaA proteins', Journa of Bacteriology 177, 7078-7085.

Kaushik, P., Kumari, S., Bharti, S.K. \& Dayal, S., 2014, 'Isolation and prevalence of Salmonella from chicken meat and cattle milk collected from local markets of Patna, India', Veterinary World 7, 62-65. http://dx.doi.org/10.14202/ vetworld.2014.62-65

Li, H., Bhaskara, A., Megalis, C. \& Tortorello, M.L., 2012, 'Transcriptome analysis of Salmonella desiccation resistance', Foodborne Pathogens and Disease 12, 11431151. http://dx.doi.org/10.1089/fpd.2012.1254

Ulanes, C., Kirchgesner, V. \& Plesiat, P., 1999, 'Propagation of TEM-and PSE-type $\beta$-lactamases among amoxicillin-resistant Salmonella spp. isolated in France', Antimicrobial Agents and Chemotherapy 43(10), 2430-2436.

Martin, L.J., Fyfe, M., Dore, K., Buxton, J.A., Pollari, F., Henry, B. et al., 2004, 'Multiprovincial Salmonella Typhimurium case-control study Steering Committee. Increased burden of illness associated with antimicrobial-resistant Salmonella enterica serotype Typhimurium infections', Journal of Infectious Diseases 189, enterica serotype Typhimurium infections',
377-384. http://dx.doi.org/10.1086/381270

Miko, A., Pries, K., Schroeter, A. \& Helmuth, R., 2005, 'Molecular mechanisms of resistance in multidrug-resistant serovars of Salmonella enterica isolated from foods in Germany', Journal of Antimicrobial Chemotherapy 56, 1025-1033. http:// dx.doi.org/10.1093/jac/dki365

Newell, D.G., Koopmans, M., Verhoef, L., Duizer, E., Aidara-Kane, A., Sprong, H. et al., 2010, 'Food-borne diseases - The challenges of 20 years ago still persist while new ones continue to emerge', International Journal of Food Microbiology 139, S3S15. http://dx.doi.org/10.1016/j.ijfoodmicro.2010.01.021

Poppe, C., Martin, L., Muckle, A., Archambault, M., McEwen, S. \& Weir, E., 2006, 'Characterization of antimicrobial resistance of Salmonella Newport isolated from animals, the environment, and animal food products in Canada', Canadian Journal of Veterinary Research 70(2), 105-114.

Roberts, M.C., 2005, 'Update on acquired tetracycline resistance genes', FEMS Microbiology Letters 245, 195-203. http://dx.doi.org/10.1016/j.femsle.2005. 02.034

Sánchez-Jiménez, M.M., Cardona-Castro, N., Canu, N., Uzzau, S. \& Rubino, S., 2010 'Distribution of pathogenicity islands among Colombian isolates of Salmonella', Journal of Infectious Disease in Developing Countries 4(9), 555-559. http://dx.doi. org/10.3855/jidc.670

Skyberg, J.A., Logue, C.M. \& Nolan, L.K., 2006, 'Virulence genotyping of Salmonella spp. With multiplex PCR', Avian Diseases 50, 77-81. http://dx.doi. org/10.1637/7417.1

Smith, S.I., Fowora, M.A., Atiba, A., Anejo-Okopi, J., Fingesi, T., Adamu, M.E., et al. 2015, 'Molecular detection of some virulence genes in Salmonella spp isolated from food samples in Lagos, Nigeria', Animal and Veterinary Sciences 3, 22-27. http://dx.doi.org/10.11648/j.avs.20150301.15

Thong, K.L., Goh, Y.L., Radu, S., Noorzaleha, S., Yasin, R., Koh, Y.T. et al., 2002, 'Genetic diversity of clinical and environmental strains of Salmonella enterica serotype Weltevreden isolated in Malaysia', Journal of Clinical Microbiology 40, 2498-2503. http://dx.doi.org/10.1128/JCM.40.7.2498-2503.2002

Thorns, C.J., 2000, 'Bacterial food-borne zoonoses', Research in Veterinary Science 19, 226-239. http://dx.doi.org/10.20506/rst.19.1.1219

Uchiya, K. \& Nikai, T., 2008, 'Salmonella virulence factor SpiC is involved in expression of flagellin protein and mediates activation of the signal transduction pathways in macrophages', Microbiology 154, 3491-3502. http://dx.doi.org/10.1099/mic 0.2008/021667-0

Van Asten, A.J.A.M. \& Dijk, J.E., 2005, 'Distribution of classic virulence factors among Salmonella spp.', FEMS Immunology and Medical Microbiology 44, 251-259. http://dx.doi.org/10.1016/j.femsim.2005.02.002 
Van Nierop, W., Dusé, A.G., Marais, E., Aithma, N., Thothobolo, N., Kassel, M. et al., 2005. 'Contamination of chicken carcasses in Gauteng, South Africa, by (1016/jijfoodmicro.2004.06.009

Varma, J.K., Molbak, K., Barrett T.J., Beebe, J.L., Jones, T.F., Rabatsky-Her, T. et al., 2005, 'Antimicrobial-resistant non-typhoidal Salmonella is associated with excess bloodstream infections and hospitalizations', Journal of Infectious Diseases 191 554-561. http://dx.doi.org/10.1086/427263
Zewdu, E. \& Cornelius, P., 2009, 'Antimicrobial resistance pattern of Salmonella serotypes isolated from food items and personnel in Addis Ababa, Ethiopia' Tropical Animal Health and Production 41, 241-249. http://dx.doi.org/10.1007/ s11250-008-9181-y

Zou, W., Al-Khaldi, S.F., Branham, W.S., Han, T., Fuscoe, J.C., Han, J. et al., 2011 'Microarray analysis of virulence gene profiles in Salmonella serovars from food/ food animal environment', Journal of Infectious Disease in Developing Countries 5(2), 94-105. 